16-1 | 2021

Spring 2021

\title{
Yellow Perils of Robert Heinlein
}

John Hickman

\section{(2) OpenEdition}

\section{Journals}

\section{Electronic version}

URL: https://journals.openedition.org/ejas/16749

DOI: 10.4000/ejas.16749

ISSN: 1991-9336

\section{Publisher}

European Association for American Studies

\section{Electronic reference}

John Hickman, "Yellow Perils of Robert Heinlein", European journal of American studies [Online], 16-1 2021, Online since 16 April 2021, connection on 08 July 2021. URL: http://journals.openedition.org/ ejas/16749; DOI: https://doi.org/10.4000/ejas.16749

This text was automatically generated on 8 July 2021.

Creative Commons License 


\title{
Yellow Perils of Robert Heinlein
}

\author{
John Hickman
}

\section{Introduction}

1 Perhaps more than any other science fiction writer of the mid to late $20^{\text {th }}$ century, Robert Heinlein has been praised and criticized for the political messages in his published fiction (Westfahl; Stover 49). Commentators have lauded Heinlein as a patriot in the National Review (Wooster); lauded him as a feminist in The New York Times (Lord); denounced him for ideological inconsistency in The New Republic (Heer); denounced him as sexist and racist in The Spectator (Priest); and denounced as a "right-winger, a libertarian nudist with a military-hardware fetish, a cold warrior" in The Los Angeles Times (Timberg). Contemporary science fiction writers continue to be artistically and politically inspired by Heinlein; with work reflecting his right libertarian or "conservatrian" (Hill) politics recognized in the Prometheus Award (Walton). Author Neal Stephenson, for example, was asked twice about the influence of Heinlein in a recent interview in the libertarian magazine Reason (Cowen 61, 64). Author Sarah A. Hoyt mentions Heinlein twice as an important influence in an interview (Weisskopf). Given the influence of Heinlein's political voice among science fiction writers and audiences together with scholarly recognition that science fiction has played a role in propagating anti-East Asian xenophobia and racism (Hickman 305; Wu 117), it is surprising that the anti-East Asian themes in Heinlein's fiction have not been systematically investigated.

2 That Heinlein's oeuvre presents ideological development from utopian socialism in his earliest writings to conservative libertarianism as he won large audiences as a protégé of John W. Campbell, the editor of Astounding magazine, is uncontroversial. Nor is the centrality of the "risk acceptant, technically competent" male protagonist in both his juvenile and adult fiction, a recurring character that attracted a large audience among college bound or college educated young white males who aspired to that sort of personal autonomy and chafed but did not necessarily rebel against social convention. Not coincidently, that is same demographic attracted to libertarianism (Kiley). 
Heinlein's ideological self-presentation was as antiracist, as in a 1952 radio broadcast wherein he asserted belief "in my whole race-yellow, white, black, brown-in the honesty, courage, intelligence, durability, and goodness of the overwhelming majority of my brothers and sister everywhere on this planet" ("Our Noble, Essential Decency"). That imposture survived scrutiny until publication of his 1964 novel Farnham's Freehold, denounced for its anti-African American racism (Disch 199-201). The controversy sparked by that book and the greater salience of anti-African American racism in $20^{\text {th }}$ century America probably helped to obscure the multiple examples of anti-East Asian xenophobia and racism in Heinlein's oeuvre. Stover and Disch ignore it entirely. Smith notes the phrase "PanAsian hordes" in the novel first serialized in 1941 under the title Sixth Column and published as a 1949 book under the title The Day After Tomorrow, yet fails to identify it as a Yellow Peril theme (142). Kilgore dodges the issue and instead lauds Heinlein as tolerant because East Asian surnames pepper the author's descriptions of the human future in space (99-100). Gifford objects that "not a single black woman character" appears in Farnham's Freehold while denying via minimization the anti-East Asian xenophobia and racism in Sixth Column/The Day After Tomorrow by noting that the author sought to excise certain racist elements and conjecturing that the term "Pan-Asian" was chosen to be "less racist" (170-171). Tucker does not identify the Yellow Peril theme in Sixth Column/The Day After Tomorrow, but notes without condemnation that the insectile "Bugs" of the 1959 novel Starship Troopers serve as a metaphor for the Chinese Communism (191-192). Panshin identifies the Yellow Peril theme in Sixth Column/The Day After Tomorrow yet fails to note anti-East Asian xenophobia and racism in Heinlein's other fiction (21-22). Clareson and Sanders acknowledge that Sixth Column/The Day After Tomorrow is racist (47-48) yet defend a scene in the 1955 novel Tunnel in the Sky in which a massive population of compliant Asians is brutally herded as a condemnation of authoritarianism (88-89). The only scene in the 1966 novel The Moon is a Harsh Mistress involving East Asians that Clareson and Sanders mention involves a Chinese official casually threatening to send unsuccessful engineers to a reeducation camp (158-159). Franklin also identifies the Yellow Peril theme in Sixth Column/The Day After Tomorrow but hesitates to name it in the 1959 novel Starship Troopers (40-52, 117-118). Patterson characterizes Heinlein as struggling to reduce the "pulpish Yellow Peril angle" in Sixth Column/The Day After Tomorrow (260). Mendlesohn also identifies the obvious Yellow Peril theme in Sixth Column/The Day After Tomorrow (97) and notes in passing the "hostility to Asian population expansion" in Tunnel in the Sky (275-276) and the hyper-entrepreneurial Chinese stereotype in The Moon is a Harsh Mistress (278), yet fails to identify or discuss other instances. These failures of recognition are consistent with its de-emphasis in studies of race and ethnicity in science fiction generally (Lavender). So this article fills an important lacuna in Heinlein scholarship and more generally in science fiction studies.

Heinlein was a popular writer both in the sense that he wrote for a mass audience and did so successfully. He is unlikely to have encountered East Asians in his hometown of Butler, Missouri, today part of the greater metropolitan Kansas City. St. Louis had a small Chinatown but it was on the other side of the state. Chinese settlement in the United States was concentrated on the West Coast, Mountain West, Northeast and Southern Delta (Chang 93-115). As a small-town Midwesterner generations removed from the immigrant experience, Heinlein stood apart from contemporaries among American science fiction writers like Isaac Asimov, Ciril Kornbluth, and Alfred Bester, who were urbanites and the children of immigrants. His first regular encounters with 
East Asians are unlikely to have happened until adulthood while he was serving in the U.S. Navy and working as a writer while living in Colorado and California. So he would have initially constructed perceptions of East Asians from popular culture and news sources, and likely continued to draw on the same material as a writer because they provided a gauge of popular opinion.

To identify the heretofore largely obscured anti-East Asian themes in his oeuvre, Lee's "six faces of the Oriental" in American popular culture is adopted as an analytic schema (8-9). Each of its theme or trope categories-Pollutant, Coolie, Deviant, Yellow Peril, Model Minority, and Gook-is a stereotypic construction of both East Asian countries and East Asians communities in the United States. Its utility for the purposes of this article derives from its comprehensiveness and discreteness. The first four themes had developed by the mid- $19^{\text {th }}$ century as is evident in Henry George's 1869 New York Daily Tribune article, "The Chinese in California." The Model Minority and Gook themes emerge in the mid- $20^{\text {th }}$ century. As will be shown in the following analysis, Heinlein exploited three of the four $19^{\text {th }}$ century themes and both of the $20^{\text {th }}$ century themes. Thus one of the giants of Golden Age science fiction managed to bestride two centuries of anti-East Asian racism and xenophobia without being caught in the act.

\section{Pollutant}

As Pollutant, Chinese were characterized as racially and culturally unassimilable, ineluctably alien outsiders either mistakenly or through malign intent allowed into the United States as immigrants (George). Native Americans were believed to be destined for extinction through population decline and African-Americans were believed to lack the intelligence to represent a serious threat to white dominance. Chinese, by contrast, were considered a threat because their population was growing and they were believed to be intelligent and competitive (Huang 127). The image of the Chinese constructed in the Victorian Era for English speaking audiences was of a people extraordinarily numerous, irrationally proud, diminutive, secretive, superstitious, and both obsequious to authority and cruel to subordinates (Del Mar 99-100; Wong 1995 3-15). The Chinese and other East Asians were viewed as heirs of a stagnant civilization, which made their countries vulnerable to foreign domination (Gregory 119-125; Sheehan 162). Initially constructed as highly ceremonious tragic aesthetes capable of erupting into unpredictable violence, the Japanese were recast as existential threats: military invaders likely to be assisted by unassimilable immigrant fifth columnists (Daniels 115-116; Stephan 56-59). Creatures so culturally alien were thought unassimilable. So extreme was the antipathy to East Asians that early $20^{\text {th }}$ century feminist essayist and novelist Charlotte Perkins Gillman described all Asian civilizations as degenerate and urged a quarantine of Asia and prohibition of Asian immigration (Nadkarni 61-62).

6 Against that backdrop consider Heinlein's 1949 young adult novel Red Planet, which describes a future Mars as a frontier populated by human colonists and a declining race of Martians, obvious analogs the $19^{\text {th }}$ century American West with settlers and natives (102-108). Disproportionately represented among the human settlers are Bolivians and Tibetans, nationalities adapted to high altitudes and capable of working without breathing apparatus in the thin Martian atmosphere. Until the 1964 Mariner Mission the atmosphere of Mars was anticipated to be thin but within terrestrial parameters (Ley 136). Heinlein uses a conversation between young American colonists and a young 
Tibetan named Chen at the colony's boarding school to evoke the passivity of Asians to tyranny:

'How about it, Chen? Are we going to put up with this?'

The Asiatic's broad face showed no expression. 'It is not worth getting excited

about.' He started to turn away.

'Huh? You mean you won't stand up for your rights?'

'These things pass.' (43-44)

7 That Heinlein would have chosen Chen, a Chinese rather than Tibetan surname, together with the reference to "the Asiatic's broad face" may have been intended to convey the idea that differences between East Asian nationalities were unimportant. The racist canard is that all East Asians are indistinguishable. What is most important in the passage is the suspect passivity in response to a chance to defend individual rights. Implicit in the exchange is the suggestion that a free society could not be constructed with or sustained by East Asians.

\section{Coolie}

As Coolie, the Chinese were characterized as cheap laborers whose acceptance of contract labor and low wages undermined the living standards of white workers (George, reprinted in Joshi 427, Lyman 123-126). Belief that the Chinese placed less value on their own lives was widespread not only in the United States but also in the other English speaking settler states like Australia (Sandmeyer, 25-56; Price 90-121; Darwin 163-164; Storti 21-25). That belief echoes in a long passage at the beginning of Heinlein's 1955 young adult novel Tunnel in the Sky, the protagonist observes a mass of impoverished and brutalized, "Asiatics-Japanese, Indonesians, Siamese, some East Indians, a few Eurasians, but predominantly South Chinese" colonists driven through a interstellar teleportation gate toward a colony world (17-18).

Rod had heard an old story which asserted that if all the Chinese on Terra were marched four abreast past a given point the column would never pass that point, as more Chinese would be born fast enough to replace those who had marched past .... Rod felt that the old canard was true even though its mathematics was faulty. There seemed to be no end of them. (18-19)

9 The colonists are emigrating from His Serene Majesty Chairman Fung Chee Mu's Australasian Republic, a future Australia overpopulated by Asians whose white inhabitants had been expelled to New Zealand. Heinlein was no doubt aware that Japanese military planners had proposed ethnically cleansing Australia by relocating white Australians to New Zealand and repopulating the island continent with Japanese colonists. However the previous passage in Tunnel in the Sky is just as easily read as inspired by then courant debates in Australia over its controversial "whites only" immigration restriction.

\section{Deviant}

As Deviant, the Chinese "practice all the unnamable vices of the East, and are as cruel as they are cowardly" (reprinted in Joshi 431). Chinese immigrants were denigrated as inscrutable, and given to opium smoking, homosexuality and sex work (Hickman 71-91). The Deviant is the only anti-East Asian theme that Heinlein does not exploit, possibly a reflection of the author's rejection of sexual prudery and disinterest in 
recreational drugs. His position on sex work was an unsentimental libertarian defense of personal autonomy (Mendelsohn 332-333). Two novels treating sex and love in detail merit mention here: Stranger in a Strange Land and Time Enough for Love: The Lives of Lazarus Long. Popular as a countercultural text, the 1961 Stranger in a Strange Land features a messianic figure who returns from Mars with a message of transcendent love, peace and permissive sexuality, in a text expressing contempt for organized religion, and in particular for Evangelical Protestantism (176-181). Perfectly timed for the early 1960s, the novel "mesmerized a generation" and generated a "youth cult mania" (Suplee). Consistent with the utopian inspiration of the Age of Aquarius, it expressed no bigotry. Indeed, one of its laudable characters is a Muslim. The 1973 Time Enough For Love develops characters and plotlines begun in earlier novels as a vehicle for musings about sex and love. The sole reference to East Asia in the work is the incidental comment that "China destroyed Europe" as a distant event used by the protagonist, Lazarus Long, to trace his own personal history (108). Recounting it echoes a pessimistic, civilizational understanding of world history popularized in the interbellum by Oswald Spengler with the publication of his two volume The Decline of the West. Both the protagonist's biblical first name and Scots-Irish surname that occurs frequently in western Missouri, flag inherited longevity that is the result of voluntary selective eugenics. The character first appears in the 1958 novel Methuselah's Children, which may be interpreted both as a critique of anti-Semitism because the long-lived minority are scapegoated by the majority and a critique of communism because the long-lived minority seek but escape subordination to a hive mind on an extraterrestrial planet. A fair reading of his oeuvre shows that Heinlein shared only some of the prejudices common to his time period.

\section{Yellow Peril}

11 In Sixth Column/The Day After Tomorrow, a novel serialized in Astounding magazine early in 1941, before the Japanese surprise attack on Pearl Harbor, Heinlein conjures menacing East Asians in the form of PanAsians who are neither Japanese nor Chinese but instead, "a mixed race, strong, proud, and prolific. From the American standpoint they have the vices of both and the virtues of neither" (26). Perhaps hesitant to endorse naked racism, Heinlein also evokes a precocious version of the Gook theme that would emerge after the Second World War by condemning the enemy for having been "duped by the old fallacy of the State as super-entity" (26). He also describes an encounter with a mixed race American character named Frank Roosevelt Mitsui, who is identified as having Japanese, Hawaiian, Chinese and white ancestry and as being "as American as Will Rogers and, and much more American than that English aristocrat George Washington" (27). Mitsui relates that the PanAsians are intent on exterminating Asian Americans and particularly "half-breeds" who do not "fit into the pattern of serfs and overlords" (28). Heinlein does not slow the pace of storytelling to explain why "mixed race" PanAsians are intent upon killing mixed race Americans.

Heinlein's PanAsians resemble the Japanese imperialists of the late 1930s and early 1940s rather more than the Chinese nationalists with whom they were then at war, with PanAsian military officers indoctrinated in the "Seven Principles of the Warrior Race" and ruling the newly occupied United States in the name of a Heavenly Emperor (56). Greater numbers and contempt for human life are the crucial advantages of the 
PanAsian occupiers: "The emperor could, if necessary, expend six million men to defeat six. The hordes of the empire could come at them barehanded and win, move over them as an avalanche moves, until they were buried under a mountain of dead flesh" (36). This summarizes the popular perception of Japanese aggression as it was constructed in newspaper and newsreel accounts of the ongoing Second Sino-Japanese War that began in 1937. Implicit in such horrific imagery is moral justification for beleaguered defenders to kill on a massive scale.

The plot in Sixth Column/The Day After Tomorrow is marched forward with the conspirators conjuring a bogus religion as a front organization to develop a secret energy weapon that incapacitates or kills only Asians $(35,122)$. Here Heinlein plays to the security concerns about subversive front organizations in Second World War and Cold War America. Although the notion of a racially targeted energy weapon sounds improbable today, the possibility of racially targeted bioweapons using genetic markers continue to be discussed seriously even today (Brooks). Heinlein instructs the audience that, "given the workings of the Oriental mind" with its proclivity for mass murder and mass suicide (125), the conspirators are justified in unleashing their own high tech massacre. Here then is a preemptive apologia for the subsequent incendiary and atomic bombings of Japan that killed hundreds of thousands of non-combatants (Werrell 227). Why might the author have been thinking in such terms? Although Heinlein did not serve in combat in the Second World War, he worked with science fiction writers Theodore Sturgeon and L. Ron Hubbard on a back channel U.S. Navy Intelligence research project (Patterson 335-336). Hubbard, curiously enough, would go on to elaborate his own new religion: Scientology.

Sixth Column/The Day After Tomorrow ends with an American insurgent victory over the PanAsian occupiers, an exclusively white victory because the mixed race American character Mitsui dies by friendly fire. "The fighting continued sporadically for hours, but it was no longer a battle; it was more in the nature of vermin extermination. Some of the Orientals surrendered, more died by their own hands; most died purposefully at the hands of their late serfs" (Heinlein 143-144). Dehumanizing epithets such as "vermin" are familiar features of exterminationist rhetoric and were commonly used to describe Japanese in wartime propaganda by the United States (Dower 81-92; Rosenberg 54-55). Rather than explain whether the phrase "died purposefully at the hands of their late serfs" meant PanAsian deaths in combat or the execution of PanAsian warriors hors de combat, Heinlein's allows the victors to gloat to the defeated that, "you know by now that you were tricked, hoaxed, by science that your culture can't match" (144). Heinlein's 1940s America was keenly aware that it enjoyed a scientific and technological advantage over Japan. Then and for decades afterward Americans and Europeans dismissed East Asians as highly disciplined and diligent but fundamentally imitative rather than creative, a characterization deployed to assuage barely acknowledged fears of Western inferiority.

When Heinlein cast the "PanAsian hordes" who conquer the United States as the Yellow Peril in Sixth Column/The Day After Tomorrow he was working with themes that had already been developed for decades. As the Yellow Peril, Chinese pose an existential threat to Americans and more generally to other Westerners. Consider this histrionic characterization: "Look at the swarming that is possible from this vast human hive! Consider that if humanity were marshaled, every third man in the line would wear the queue and the blouse of a Chinaman; that this half billion people would throw off 
annually six, ten, twenty millions of emigrants, and this not merely without feeling the loss, but without there being any loss, for over-population keeps reproduction down, and new Chinamen would spring into the vacancies created by those who left as air into a vacuum" (George). The animal analogy images of swarming and hives rhetorically dehumanize East Asians as insects, something would later do in his novel Starship Troopers. From the late $19^{\text {th }}$ to the mid- $20^{\text {th }}$ century nativist agitation in the United States and other white settler states encouraged racial anxiety that Chinese and Japanese immigrants and their descendants would displace white populations and serve as the fifth column for the territorial aggrandizement by China, Japan or both (Lyman 82-89). As late as the Second World War, U.S. Representative Carl Curtis of Nebraska could still voice fear about a race war in which East Asians would prevail over whites (Dower 168).

Consider these possible inspirations for Sixth Column/The Day After Tomorrow. In his 1880 short story, "The Battle of the Wabash," Lorelle describes a climatic battle fought at the Wabash River between armies of whites and Chinese on November 3-4, 2081 (Lorelle 364). The author explains that the 2070 Census revealed that the Chinese outnumbered whites in the United States by 2.3 to 1, the result of two centuries of unrestricted Chinese immigration, intermarriage, and both higher Chinese birthrates and minimal Chinese wartime casualty rates due to their refusal to accept conscription. In victory, the once mild Chinese are ordered by the Chinese Emperor's Viceroy to punish the conquered with rape, murder and arson for 100 days. "[T]he Republic fell at the Wabash, broken into a million fragments; her people passed into Asiatic slavery. The fruit-time of folly had come" (Lorelle 364). Chinese and Japanese immigrant communities as racial and cultural fifth columns is highlighted in early $20^{\text {th }}$ century military fantasies of the United States defeated by an East Asian great power. Marsden Manson's 1907 novella The Yellow Peril in Action: A Possible Chapter in History is uncannily reminiscent of Heinlein's Sixth Column/The Day After Tomorrow. Manson describes a near future war in which the Allied Asiatic Powers-China and Japan-attack the United States. Hawaii is lost because Chinese and Japanese laborers on the islands are an army in waiting for Chinese and Japanese ships to land uniforms and weapons. With the defense of the West Coast crippled by sabotage of the railways by Chinese and Japanese laborers and American commerce in the Pacific halted by enemy fleets blockading West Coast ports, Washington accepts a humiliating peace. Similarly, Parabellum's 1908 novel Banzai! portrays a surprise attack on the United States in the invading Japanese Army is supported by as immigrant Japanese and Chinese laborers (Parabellum 40).

The Yellow Peril also makes a brief appearance in Heinlein's 1942 novel Beyond This Horizon, which presents a voluntary eugenic utopia in which the bulk of humanity has been freed from inherited disease as well as physical and mental weakness. However, the novel also warned against the possibility that authoritarians might eugenically reproduce humans for either passivity or violence. Readers are instructed that the utopia described in the novel survived an existential conflict three centuries earlier against an Empire of the Great Khan, which had breed superhuman with physical strength yet slavishly dependent on their masters (27-28). That Heinlein's East Asians lack individual autonomy is implicit justification for denying them the rights of a complete humanness. 


\section{Model Minority} revolution on the Moon turned penal colony. Set in 2075, the Chinese and other subject peoples on Earth continue to be tyrannized by the government of China. Hong Kong Luna is the settlement where, "Great China dumped what she didn't want there, first from old Hong Kong and Singapore, then Aussies and Enzees and black fellows and marys and Malays and Tamil and name it. Even old Bolshies from Vladivostok and Harbin and Ulan Bator" (21). Use of the term "old Bolshies," referencing the Stalinist liquidation of the Old Bolsheviks (Medvedev 328, 472), is perhaps the book's most patent logical flaw. By 2075 any veterans of the Russian Revolution would have been dead for decades. While multi-ethnic, Hong Kong Luna is notably a lunar settlement apparently dominated by Chinese, a people determined to remain apart. Here then is a reiteration of the belief that the ghettoization of the Chinese in the United States in Chinatowns was voluntary rather than coerced, a reflection of cultural insularity rather than racist discrimination and violence (Wong, Americans First 7-8). Note too that as with the future forecast in Tunnel in the Sky, the future forecast in The Moon is a Harsh Mistress features an ethnic cleansing by Chinese of whites from Australia.

Unlike the populations of the other named major lunar settlements described in The Moon is a Harsh Mistress, Luna City, Novy Leningrad, Churchill and Tycho Under, which responded to the unbalanced sex ratio of the penal colony with group marriages, ethnically East Asian Hong Kong Luna maintains its traditional patriarchal clans (31). Heinlein's culturally insular Chinese are possessed of business acumen and a talent for technical imitation. The banks of Hong Kong Luna are run by "honest Chinee bankers" and what is more a "Chinee engineer given a look at anything can figure way to make it” (123-134). Insularity makes Hong Kong Luna's residents reluctant to risk making revolution with other "Loonies." They are, in that sense, like the Chinese who free ride on the sacrifices of whites by avoiding conscription in Lorelle's "Battle of the Wabash." Publishing in 1966 about events to occur in 2075, Heinlein thus Othered East Asians in the same manner as Lorelle had in 1880.

The narrator and male protagonist Manuel Garcia O'Kelly must recruit Comrade Clayton to organize Hong Kong Luna for the coming rebellion. Heinlein has his protagonist describe Clayton as a, "young Japanese-not too young, but they all look young till suddenly look old. He was not all Japanese-Malay and other things-but had Japanese name and household had Japanese manners" (123). To recruit Clayton as revolutionary comrade, O'Kelly must endure two hours of discussions about everything but politics in a teahouse before Clayton concludes that he is trustworthy. Racial and cultural difference the entirety of Clayton's identity as a character.

The Model Minority theme makes its debut the same year that The Moon is a Harsh Mistress is published. University of California at Berkeley Sociology Professor William Peterson launched the seemingly positive theme in a January 9, 1966 New York Times Magazine article, "Success Story, Japanese-American Style." Japanese-Americans and more generally other East Asian Americans are characterized as successful because of their "stoic patience, political obedience, and self-improvement," a stereotype which reproved the social, economic and political "impatience" of African-Americans, Hispanics and Native Americans who dared to complain of social and economic discrimination in an era of general prosperity (Lee 145). Chastising African-Americans 
as given to "self-defeating apathy or a hatred so all-consuming as to be selfdestructive," Peterson lauded Japanese-Americans as having become, by "any criterion of citizenship," "better than any group in our society including native born whites" (Petersen 2). What the Model Minority tends to elide the ugly history of discrimination and violence experienced by East Asians in the United States and their long struggle to win civil rights. The Chinatowns to which Chinese immigrants fled from persecution might be exotic but no different than the white ethnic urban neighborhoods that emerged spontaneously in response to cultural affinity. Heinlein's Hong King Luna is an American Chinatown on the Moon, its inhabitants are successful because they brought their East Asian talents to bear in an oppressive new environment. Alas they cannot be entirely trusted because of that success.

\section{Gook}

As Gook, the Pollutant and Yellow Peril fuse in the Cold War as a civilizational and ideological existential threat, taking the new form of East Asian communism fanatically committed to the destruction of the United States. "Bemusement, fear, loathing, and at times an alarmed respect," is how Julia Lovell characterized American views of China during the Cold War (89). American public opinion was alarmed by the victory of Mao Zedong's Red Army in China in 1949 and by the near victory of the North Korean invasion of South Korea in 1951 (Mann 25-28, 55-57), events precipitating the Red Scare of the McCarthy Era. The victory of the Viet Minh over the French Foreign Legion at Dien Bien Phu in 1954 only reinforced the belief that communism was on the march across Asia. "Mongol horde" imagery in which "human wave" attacks by Chinese, Korean or Vietnamese armies would overwhelm Western armies tapped pre-Cold War demographic anxieties (Lyman 96-97: Connelly 161). Those images resonated beyond the Global North. Brutality toward American prisoners of war by East Asian enemies born of ideological fanaticism was a common element in U.S. official statements during the Second World War, Korean War, and War in Vietnam (Casey 279-289; Ayers 77).

Heinlein's 1959 novel Starship Troopers offers the Gook thinly disguised as an enemy alien species of "Bugs." Although the Bugs have been read naïvely as extraterrestrial (Perkowitz 33-34), they are metaphors for East Asians against whom Americans fought in the Second World War in the Pacific and in the Korean War, and would fight in the War in Vietnam after Starship Troopers was published. The parallels are simply too numerous to ignore. The Bug War erupted after the Bugs raid Earth and destroy Buenos Aires (151), just as the Second World War in the Pacific erupts after the Japanese raid Pearl Harbor in 1941. The Terran Federation battles the Bugs planet by planet just as the United States waged war against Japan island by island. The Bug home world of Klendathu is subjected to a nuclear bombardment, just as was Japan in 1945. Crucially, the Bugs pose an existential threat to the survival of humanity, as a merciless enemy Other with whom negotiation is pointless and for whom that it is permissible, indeed righteous, to hate.

Heinlein's Bugs lack individuality, which is consistent with the stereotype of lookalike East Asians indoctrinated in belief systems denying individuality (223). 'The bugs are not like us. The Pseudo-Arachnids aren't even like spiders. They are arthropods who happen to look like a madman's conception of a giant, intelligent spider, but their organization, psychological and economic, is more like that of ants and termites; they 
are communal entities, the ultimate dictatorship of the hive' (134-135). Though every few species of spider are social, they were likely chosen because ants and termites typically arouse less fear. What is a bit of bad entomology to an author willing to appeal to barely disguised racism?

The animal analogy is made absolutely plain for the reader in the following passage instructing them that they have fought this race war before:

We are learning how efficient a total communism can be when used by a people actually adapted to it by evolution; the Bug commissars didn't care any more about expending soldiers than we cared about expending ammo. Perhaps we could have figured this out about the Bugs by noting the grief the Chinese Hegemony gave the Russo-Anglo-American Alliance; however the trouble with "lessons from history" is that we usually read them best after falling flat on our faces.' (152-153)

This passage evokes shock about human wave attacks, infantry assaults sacrificing large numbers of soldiers to overwhelm defenses, by the Japanese Imperial Army in the Second World War and by the Chinese People's Liberation Army in the Korean War. The same squandering of lives characterized the First World War and Second World War in Europe, though there it was constructed as patriotic heroism.

The Bugs also make extensive use of defensive tunnels (224), as did the Japanese military in the Battle of Okinawa (Ienaga 198-199). For those who read Starship Troopers in the decades after it was published, references to fighting an enemy in tunnels would doubtless conjure images of the U.S. Army's struggle with the Vietnamese National Liberation Front (Mangold and Penycate 56-60; Jones 19, 31) and the tunnels excavated under the Korean Demilitarized Zone by the Korean People's Army (Oberdorfer 56-59).

Critical reception of the novel has largely ignored its anti-East Asian themes, focusing instead on its endorsement of corporal punishment, genocidal warfare, and militarist conception of citizenship (Disch 165-166). The Terran Federation grants suffrage only to those who have served in an all-volunteer military, a fusion of conservative and libertarian political impulses. Conceiving war against existential threats to justify mass murder appealed to the former while criticism of military conscription appealed to libertarian opponents of the draft in the 1960s.

\section{Significance and Motivation}

Why the suffusion of anti-East Asian themes in Heinlein's oeuvre matters and what motivated Heinlein to propagate them are intertwined. They matter because they are ethically repugnant from a consequentialist perspective. Not only might their propagation exact an immediate emotional cost to East Asians in the reading audience, but they are also the source of hateful images that inform popular understandings of international and domestic politics and of duty to others, including vulnerable racial and ethnic Others. Stereotypic characterizations of good and evil in works of fiction tend to define the boundaries of the moral universe for uncritical mass audiences, determining whether, which, and to what degree moral duties are owed to members of the stereotyped group. As a potentially powerful form of persuasive discourse, fiction populates the popular imagination with international and domestic friends and enemies (Callans 29-30, 63). Audiences are taught that foreign countries merit either trust and peace or suspicion and war. Audiences are taught that members of ethnic minorities sharing something of the identity and culture of those foreign countries 
merit trust and respect or suspicion and discrimination. And the linkage between those teachings is especially taut for East Asian countries and East Asian ethnic minorities.

McCracken described the core of all science fiction as an exciting, fearful or erotic encounter with the alien Other (102). Although difficult to credit in the relatively cosmopolitan present, East Asians represented perhaps the most important alien Other for late $19^{\text {th }}$ and early $20^{\text {th }}$ century Americans. Although temporarily humbled by their encounters with the great powers of Western Europe and the United States, China was home to an enormous population that was heir to a high culture which owed little to the civilizations of the ancient Near East and Eastern Mediterranean revered in the West. East Asians stubbornly and often successfully resisted Western European and American imperialism. Rather than succumb like almost every other society in the Global South, China and Japan maintained their sovereignty. Japan proved so adept at emulating the Western imperial great powers that it joined their number within two generations of the Meiji Restoration. The awesome potential future power of a modernized China was captured in the cliché that the Middle Kingdom was a 'sleeping dragon' which the rest of the world should fear awakening. For Westerners generally, Chinese and Japanese inhabited an exotic realm where conventional expectations were upended with a degree of cultural confidence presented nowhere else in the Global South.

31 Crucially for Americans, the Chinese and Japanese were not just present on the other side of the Pacific but on this side as well, and more clearly wanted to arrive. Scapegoating ethnic minorities as the disloyal agents of threatening foreign powers is a time dishonored tactic of nationalists. Anti-East Asian themes of the $19^{\text {th }}$ century deployed in nativist or populist agitation in the United States against Chinese and Japanese immigration took the form of proto-science fiction describing a near future East Asian conquest (Claeys 301-302; Lyman 75-76).

Chinese and Japanese immigration to the United States had been reduced to a trickle in the four decades before Heinlein began his publishing career and did not grow until the latter years of his publishing career. Why anti-East Asian themes? The answer is probably opportunity. His readers were the grandchildren and children of readers who had been exposed to anti-East Asian xenophobic agitation. Invidious stereotypes wither over time from disuse but it takes many generations for them to be eradicated. Heinlein's other fiction reveals a familiarity with the survival of homespun ideas in popular culture, as shown in background descriptions of protagonists that include life in the author's own home state of Missouri.

33 More importantly, however, East Asians were the only racial and ethnic Others Heinlein could safely target. By the 1940s, Jews, other white ethnics, AfricanAmericans, Native Americans and Hispanics were off-limits among publishers and educated readers, who recognized them as victims of oppression and as contributors to the war effort.

East Asians thus serve as the necessary exception in the ethnic and racial inclusion endorsed by American liberalism (Vogt 62). Relatively few in number, East Asians were traumatized by stigmatizing isolation-Chinatowns in the case of the Chinese and internment in the case of the Japanese-and burdened with a racial and cultural exoticism not borne by German Americans and Italian Americans. In effect, Heinlein chose his targets with the same calculation made by a schoolyard or institutional bully. Although the Japanese experienced a "rehabilitation" of sorts during the Cold War, the 
Korean War and the Vietnam War only reinforced the Othering of the Chinese and added the other East Asians to their number. The Cold War thus gave Heinlein even more license to exploit the same prejudices.

\section{Conclusion}

Although unlikely to please his contemporary admirers, Heinlein's success is attributable in part to his willingness to pander to anti-East Asian xenophobia and racism. He repeatedly played to the invidious stereotypes of East Asian societies and East Asian communities in the United States. This analysis showed that Heinlein exploited five of Lee's six themes: Pollutant, Coolie, Yellow Peril, Model Minority and Gook. Only the Deviant theme is missing. His East Asians pose threats as aggressive totalitarians contemptuous of human life who attack in overwhelming hordes and as immigrants who too insular, grasping or passive to make common cause in struggles for freedom. As individually named characters, East Asians are peripheral to the drama, never more than representatives of or exceptions to their invidious stereotypes.

Implicit in the racist constructions of East Asians Heinlein repeatedly evoked by Heinlein is justification not only for discrimination at home but for mass murder abroad. In propagating prejudices against East Asians in the guises of patriotism during the Second World War and anti-communism during the Cold War, his fiction offered readers dispensation to fear and hate, and therefore to unleash indiscriminate violence. The 20th century saw the United States kill hundreds of thousands of Japanese, Korean, Vietnamese, Laotian and Cambodian noncombatants in history's largest aerial bombardments (Grosscup 66-69; 77-93), wartime decisions that, with the exception of the atomic bombings of Japan, many Americans are unaware of and few Americans recognize as violations of the laws of war. Heinlein got away with it because his publishers accepted the exception to the racial and ethnic inclusiveness endorsed by American liberalism and his audience failed to recognize the racist themes.

Anti-East Asian xenophobia and racism have seen an alarming resurgence during the current pandemic. Endorsement by powerful political elites is largely responsible, but the fear and hate they aroused lay dormant in the popular culture because writers like Heinlein had exploited them without challenge.

\section{BIBLIOGRAPHY}

Ayers, Bill. Fugitive Days. Beacon P, 2001.

Brooks, Rosa. “Can There Be War Without Soldiers?” Foreign Policy. 15 March 2016, https:// foreignpolicy.com/2016/03/15/can-there-be-war-without-soldiers-weapons-cyberwarfare/. Accessed 21 November 2019.

Casey, Steven. Selling the Korean War: Propaganda, Politics, and Public Opinion in the United States, 1950-1954. Oxford UP, 2008. 
Challans, Timothy L. Awakening Warrior: Revolution in the Ethics of Warfare. State UP of New York, 2007.

Chang, Iris. The Chinese in America: A Narrative History. Penguin, 2003.

Claeys, Gregory. Dystopia: A Natural History. Oxford UP, 2017.

Clareson, Thomas D., and Joe Sanders. The Heritage of Heinlein: A Critical Reading of the Fiction. McFarland, 2014.

Connelly, Matthew. Fatal Misconception: The Struggle to Control World Population. Belknap P, 2008.

Cowen, Tyler. "Neal Stephenson Wants to Tell Big Stories.” Reason, vol. 51, no. 2, 2019, pp. 59-66.

Daniels, Roger. Asian Americans: Chinese and Japanese in the United States Since 1850. Seattle: U of Washington P, 1992.

Darwin, John. 2009. The Empire Project: The Rise and Fall of the British World-System 1830-1970. Cambridge UP, 2009.

Del Mar, David Patterson. Beaten Down: A History of Interpersonal Violence in the West. U of Washington P, 2002.

Disch, Thomas M., The Dreams Our Stuff is Made Of: How Science Fiction Conquered the World. Touchstone, 1998.

Dower, John W., War Without Mercy: Race \& Power in the Pacific War. Pantheon, 1986.

Franklin, H. Bruce. Robert Heinlein: America as Science Fiction. Oxford UP, 1980.

George, Henry. “The Chinese in California.” New-York Daily Tribune, 1 May 1868, pp 1-2, in S.T. Joshi, editor, Documents of American Prejudice: An Anthology of Writings on Race from Thomas Jefferson to David Duke, Basic Books, 1999, pp. 425-432.

Gifford, James. Robert Heinlein: A Reader's Companion. Nitrosyncretic P, 2000.

Gregory, John S. The West and China Since 1500. Palgrave Macmillan, 2003.

Grosscup, Beau. Strategic Terror: The Politics and Ethics of Aerial Bombardment. Zed P, 2006.

Heer, Jeet. “A Famous Science Fiction Writer's Descent into Libertarian Madness.” The New Republic, 14 June 2014, https://newrepublic.com/article/118048/william-pattersons-robertheinlein-biography-hagiography. Accessed 30 Sep. 2019.

Heinlein, Robert A., Beyond This Horizon. The New American Library, 1942.

---. Methuselah's Children. Signet, 1958.

---. “Our Noble, Essential Decency." “This I Believe.” CBS Radio, 1952, http://thisibelieve.org/ essay/16630/. Accessed 4 July 2020.

---. Red Planet. Ballantine Books, 1949.

---. Starship Troopers. Ace Books, 1987.

---. Stranger in a Strange Land. Ace, 1991.

---. Time Enough For Love: The Loves of Lazarus Long. G.P. Putnam’s Sons, 1973.

---. Tunnel in the Sky. Ace, 1955.

Herwig, Holger W. “Luxury” Fleet: The Imperial German Navy, 1888-1918. George Allen \& Unwin, 1980. Hickman, John. "Implacable Justice: Arguing Politics and Theories of Law via the Encounter with Powerful Alien Species.” Extrapolation, vol. 48, no. 2, Summer 2007, pp. 302-313. 
Hickman, Timothy A. "Drugs and Race in American Culture: Orientalism in the Turn-of-theCentury Discourse of Narcotic Addiction." American Studies, vol. 41, no. 1, Spring 2000, pp. 71-91. Hill, Jordan Alexander. "The Libertarian History of Science Fiction.” Quillette, 22 June 2020, https://quillette.com/2020/06/12/the-libertarian-history-of-science-fiction/. Accessed 25 July 2020.

Huang, Yunte. Charlie Chan: The Untold Story of the Honorable Detective and His Rendezvous with American History. W.W. Norton, 2010.

Ienaga, Saburō. The Pacific War, 1931-1945. Pantheon, 1978.

Jones, Howard. My Lai. Oxford UP, 2017.

Kiley, Jocelyn. "In Search of Libertarians." Pew Research Center, 25 Aug. 2014, https:// www.pewresearch.org/fact-tank/2014/08/25/in-search-of-libertarians/. Accessed 31 July 2020.

Kilgore, De Witt Douglas. Astrofuturism: Science, Race, and Visions of the Future. U of Pennsylvania P, 2003.

Lavender, Isiah. Race in American Science Fiction. Indiana UP, 2011.

Lee, Robert G., Orientals: Asian Americans in Popular Culture. Temple UP, 1999.

Ley, Willy. “The Redesigned Solar System." Galaxy, vol. 24, no. 4, April 1966, pp. 131-136. https:// archive.org/stream/Galaxy_v24n04_1966-04\#page/n62/mode/1up. Accessed 17 Nov 2019.

Lord, M.G., "Heinlein's Female Troubles.” The New York Times, 2 Oct. 2005. https:// www.nytimes.com/2005/10/02/books/review/heinleins-female-troubles.html. Accessed 1 Oct. 2019.

Lorelle. "The Battle of the Wabash." Californian, vol.11, no. 10, October 1880, p. 364.

Lovell, Julia. Maoism: A Global History. Alfred A. Knopf, 2019.

Lyman, Stanford M. Roads to Dystopia, Sociological Essay on the Post Modern Condition. U of Arkansas P, 2001.

Mangold, Tom, and John Penycate. The Tunnels of Cu Chi. Berkley Books, 1985.

Mann, Robert. A Grand Delusion: America's Descent into Vietnam. Basic Books, 2001.

Manson, Marsden. The Yellow Peril in Action: A Possible Chapter in History. San Francisco, unknown publisher, 1907.

McCoy, Alfred C. Policing America's Empire: The United States, the Philippines, and the Rise of the Surveillance State. U of Wisconsin P, 2009.

McCracken, Scott. PULP: Reading Popular Fiction. Manchester UP, 1998.

Medvedev, Roy. Let History Judge: The Origins and Consequences of Stalinism. Columbia UP, 1989.

Mendelson. Farah. The Pleasant Profession of Robert Heinlein. Unbound, 2019.

Morris, A.J.A. The Scaremongers: The Advocacy of War and Rearmament 1896-1914. Routledge, 1984.

Nadkarni, Asha. Eugenic Feminism: Reproductive Nationalism in the United States and India. U of Minnesota P, 2014.

Oberdorfer, Don. The Two Koreas: A Contemporary History. Basic Books, 1997.

Panshin, Alexei. Heinlein in Dimension: A Critical Analysis. Advent:Publishers, 1968. 
Parabellum. 1908. Banzai! Leipzig, Theodor Weicher, The Gutenburg Project, https:// flexpub.com/ofpreview/banzai-by-parabellum. Accessed 18 Nov. 2019.

Patterson, William H., Robert Heinlein: In Dialogue With His Century. Volume 1. 1807-1948 Learning Curve. A Tom Doherty Associates Book, 2010.

Perkowitz, Sidney. Hollywood Science: Movies, Science, \& the End of the World. Columbia UP, 2007. Petersen, William. “Success Story, Japanese-American Style.” The New York Times Magazine, 9 Jan. 1966, pp. 1-9. http://reappropriate.co/wp-content/uploads/2019/09/Petersen.pdf. Accessed 25 Nov. 2019.

Price, Charles A., The Great White Walls Are Built: Restrictive Immigration to North America and Australasia. 1836-1888. Australian National UP, 1974.

Priest, Christopher. “Robert Heinlein: The 'Giant of SF' Was Sexist, Racist-And Certainly No Stylist.” The Spectator, 30 March 2019, https://www.spectator.co.uk/2019/03/robert-a-heinleinthe-giant-of-sf-was-sexist-racist-and-certainly-no-stylist/. Accessed 30 Sep. 2019.

Rosenberg, Emily S., A Date Which Will Live: Pearl Harbor in American Memory. Duke UP, 2003. Sandmeyer, Elmer Clarence. The Anti-Chinese Movement in California. U of Illinois P, 1991. Sheehan, Neil. A Bright Shining Lie: John Paul Vann and America in Vietnam. Random House, 1988. Simpson, A.W. Brian. In the Highest Degree Odious: Detention Without Trial in Wartime Britain. Clarendon Press, 1994.

Smith, Philip E. "The Evolution of Politics and the Politics of Evolution: Social Darwinism in Heinlein's Fiction." Robert Heinlein, edited by Joseph D. Olander and Martin Harry Greenberg, Taplinger Publishing, 1978, pp. 137-171.

Spengler, Oswald. The Decline of the West: Form and Actuality, Vol. 1. Translated by Charles Francis Atkinson, Alfred A. Knopf, 1926.

---. The Decline of the West: Form and Actuality, Vol. 2. Translated by Charles Francis Atkinson, Alfred A. Knopf, 1928.

Stephan, John J., Hawaii Under the Rising Sun: Japan's Plans for Conquest After Pearl Harbor. U of Hawaii P, 1984.

Storti, Craig. Incident at Bitter Creek: The Story of the Rock Springs Chinese Massacre. Iowa State UP, 1991.

Stover, Leon. Robert Heinlein. Twayne Publishers, 1987.

Suplee, Curt. "In the Strange Land of Robert Heinlein.” Washington Post, 5 Sep. 1984, https:// www.washingtonpost.com/archive/lifestyle/1984/09/05/in-the-strange-land-of-robertheinlein/b7a2ee22-0a6e-4c29-8fc1-88b3e68ec08c/. Accessed 8 Feb. 2021.

Timberg, Scott. “The Descent of a Sci-fi Guru.” Los Angeles Times, 9 Dec. 2007, https:// www.latimes.com/archives/la-xpm-2007-dec-09-ca-heinlein9 story.html?fbclid=IwAR1tjgndpuDxVUW0n09lSw_-71T9mJnVaLt6-Uxm7a9cj95knYHkRjtOjg. Accessed 1 Oct. 2019.

Tucker, Frank H.. “Political and Social Elements in Heinlein's Fiction.” Robert Heinlein, edited by Joseph D. Olander and Martin Harry Greenberg, Taplinger Publishing, 1978, pp. 172-193.

Vogt, Erik. “Exception in Žižek's Thought.” Diacritics, vol. 37, no. 2/3, 2007, pp. 61-77.

Walton, Jo. “Something Else Like...Heinlein.” Tor.com. 28 Oct. 2012, https://www.tor.com/ 2012/10/28/something-else-like-heinlein/. Accessed 17 Oct. 2019. 
Weisskopf, Toni. “Sarah A. Hoyt.” Baen.com. Oct. 2006. https://www.baen.com/Interviews/ inthoyt. Accessed 17 Oct. 2019.

Werrell, Kenneth P., Blankets of Fire: U.S. Bombers over Japan during World War II. Smithsonian Institution P, 1996.

Westfahl, Gary. "The Joke Is on Us: The Two Careers of Robert Heinlein.” Locus, 25 Nov. 2012, https://locusmag.com/2012/11/the-joke-is-on-us-the-two-careers-of-robert-a-heinlein/.

Accessed 17 Oct. 2019.

Wong, K. Scott. “Chinatown: Conflicting Images, Contested Terrain.” MELUS, vol. 20, no. 1, 1995, pp. 3-15.

---. Americans First: Chinese Americans and the Second World War. Harvard UP, 2005.

Wu, Frank H., Yellow: Race in America Beyond Black and White. Basic Books, 2002.

\section{ABSTRACTS}

Yellow Peril and other anti-East Asian themes are a recurring but rarely acknowledged feature of the oeuvre of Robert A. Heinlein. Still revered by an overwhelmingly white, male and ideologically libertarian readership, the "Dean" of American Science Fiction made extensive use of threatening, hateful or contemptible images of East Asians in novels that appeared from the 1930s through the 1960s. The contradiction between Heinlein's self-portrayal as broad minded and unbiased on issues of race and religion and the descriptions of East Asians as menacing and untrustworthy Others that suffuse his fiction has not been systematically investigated until now. Exposing Heinlein matters because he continues to enjoy a large readership and inspires other science fiction authors. The stereotyping expressed in novels like The Moon is a Harsh Mistress and the dehumanization expressed in novels like Starship Troopers continue to shape the social and political attitudes of non-East Asian Americans both in domestic race and ethnic relations and in international affairs.

\section{INDEX}

Keywords: anti-East Asian, Cold War, imposture, xenophobia, genocide

\section{AUTHOR}

\section{JOHN HICKMAN}

John Hickman is Professor of Political Science at Berry College, where he teaches comparative politics and international relations. He is the author of the 2013 Selling Guantánamo (University Press of Florida)which was published in 2020 by Peter Lang in Spanish translation as Vendiendo Guantánamo. He holds a Ph.D. in political science from the University of Iowa and a J.D. from Washington University, St. Louis. Before earning his doctorate he taught at Reitaku University in Japan and served as a Woodrow Wilson Fellow at the Florida A\&M University. 